\title{
In vitro Propagation of Medicinally Valuable Traditional Banana Cultivar, Musa acuminata cv. Matti by Shoot Tip Culture
}

\author{
S. Merina Prem Kumari", S. Saravanan and M. Arumugam Pillai
}

Dept. of Plant Breeding and Genetics, Agricultural College \& Research Institute, Killikulam, Vallanad, Thoothukudi District-628252, India

*Corresponding author

\section{A B S T R A C T}

Matti is an important medicinally valuable traditional banana variety of southern parts of Tamil Nadu in India. In order to popularize the variety, the propagule availability is a

\section{Keywords}

Banana, Medicinal value, Matti, Shoot tip Culture,

Micropropagation

Article Info

\section{Accepted:}

20 July 2020

Available Online:

10 August 2020 major constraint and micropropagation is a promising technique for mass production. The sword suckers were collected from Pechiparai, Kanyakumari district, Tamil Nadu and were thoroughly washed and sterilized with various antibiotics and chemicals. The sterilization protocol using ampicillin $100 \mathrm{mgl}^{-1}$ and $4 \%$ sodium hypochlorite was superior in producing $87.5 \%$ contamination free cultures and the survival rate was $81.3 \%$. The sterilized shoot tip explants inoculated in $\mathrm{MS}+\mathrm{BAP} 2 \mathrm{mgl}^{-1}+\mathrm{NAA} 0.1 \mathrm{mgl}^{-1}$ media recorded faster shoot initiation. Multiple shoot formation was efficient in the proliferation media, MS + BAP $4 \mathrm{mgl}^{-1}+$ NAA $0.05 \mathrm{mgl}^{-1}$. The root initiation was earlier in half MS media with IBA $0.5 \mathrm{mgl}^{-1}$ and IAA $0.5 \mathrm{mgl}^{-1}$. The in vitro regenerated plantlets were subjected to acclimatization in substrate containing cocopeat, farm yard manure and sand in 1:1:1 ratio and $100 \%$ survival was observed. Primary hardened plants recorded the plant height of $6.9 \mathrm{~cm}$ and during secondary hardening, the plantlets reached the height of $10.8 \mathrm{~cm}$. The hardened plants were then transferred to field showing normal growth. This in vitro regeneration protocol for banana cv. Matti can be used for micropropagation in order to produce plantlets for dissemination.

\section{Introduction}

Banana (Musa sp.) is a nutritious food, adequate in carbohydrates, vitamins and minerals like potassium and iron. Also it is an economically important fruit crop and staple food of people in the humid tropics. Banana is cultivated in almost all parts of India and some primitive cultivars are grown in specific areas. Matti otherwise called Dhevankadali with diploid genome AA is one among these cultivars and is selectively cultivated in the southern parts of India comprising of the states, Tamil Nadu, Kerala and Karnataka. Matti is mostly grown in homestead cultivation and also it is commercially cultivated.

It is a traditional table banana cultivar of medicinal value and the fruit is highly fragrant, sweet with sub acid flavor, firm texture and powdery nature. The fruit is used 
as baby food and has medicinal value for health improvement. The tribes of Western Ghats use the corm extract of Matti for curing from jaundice. Because of the long keeping quality of the fruit and due to its nutritious and medicinal value, it fetches high price in the market. The production rate of the fruit is moderate and the plant is tolerant to leaf spot disease and susceptible to Fusarium wilt and banana bract mosaic virus. Disease free plantlets production is required for commercializing the cultivation of Matti banana for which micropropagation is the effective way of multiplying large amount of genetically identical plantlets. The success of in vitro regeneration technique involves the maintenance of aseptic conditions for microbial contamination-free explants.

Microbial contamination is a major hurdle if the explant source is from field grown plants. Various sterilization procedures have been adopted by several researchers (Muhammad et al., 2004); (Molla et al., 2004); (Titov et al., 2006); (Bohra et al., 2013). Losses due to microbial contamination at every subculture is $3-15 \%$ in both commercial set-up and scientific laboratories; (Leifert and Waites, 1994). The sterilization chemicals used for explant treatment is toxic to plant tissues and hence the appropriate concentration of sterilants and exposure duration have to be arrived to increase the survival rate of the explant. Hence commonly used sterilants in various concentrations and exposure time are used in this research for explant sterilization to achieve maximum survival of the explant for regeneration.

Banana micropropagation protocol is well established and commercially adopted for producing large number of plants in many varieties. Many reports are available on banana micropropagation using shoot tip explants and even then banana plants exhibit great variation under in vitro conditions in the aspects of shoot multiplication, shoot establishment and root formation due to various factors like genotype, explant type, culture media composition, growth hormones and culture conditions (Vuylsteke, 1998). The endogenous level of auxins and cytokinins play a role in the organogenesis of in vitro culture of higher plants (Pierik, 1987).The cultures obtained from the same genotype also showed variations in the rate of regeneration by invitro culture (Israeli et al.,1996) and (Mendes et al.,1996); (Razani et $a l ., 2019)$. This has also been in proved by various authors in the banana cv. Matti due to its varying response to hormones and its concentrations (Rustagi et al.,2015); (Lohidas and Sujin, 2015); (Mukunthakumar and Seeni, 2005).

By keeping in view of the above mentioned findings, this research is formulated to study the effect of various hormones and its levels for regeneration of shoot tips from Matti, that would serve as an efficient micropropagation protocol for this traditional and highly delicious banana. The success of in vitro multiplication is based on the differentiation of plant tissues, by addition of required growth hormones in appropriate quantities (Gaspar et al., 2003); (Qamar et al., 2015); (Sipen and Davey, 40); (Ngomuo et al., 2013); (Pradhan and Deo, 2019). Henceforth this study is aimed to find out the best combination of growth regulators and optimize its concentration for better regeneration rate of the banana $\mathrm{cv}$. Matti in order to mass produce and popularize the variety to different geographical locations.

\section{Materials and Methods}

\section{Explant collection and pretreatment}

Healthy word suckers of three months old were collected from the fields of northern parts of Kanyakumari district, the region 
which comes under semi-arid and dry subhumid climate and the soil of deep rich loamy and salty clay loam type with $\mathrm{pH}$ 5.5-7.0. The suckers were prepared by washing thoroughly in tap water to remove the soil adhering to it. The rhizome was trimmed and the outer whorls of the pseudostem were removed using a clean stainless steel knife. The shoot tip explant with rhizome base is obtained with the size of $5 \mathrm{~cm}$ shoot length and $3 \mathrm{~cm}$ rhizome diameter. The explant is washed thoroughly using tap water and immersed in a fungicide solution of $0.1 \%$ Bavistin for $2 \mathrm{hrs}$. The explants were washed three times and transferred to a beaker containing water with two drops of Tween 20 and kept for a minute. Later the explants were washed thoroughly in running tap water for nearly 20 minutes.

\section{Explant sterilization using antibiotics and sterilizing chemicals}

The word suckers are collected from the field and there is high risk of microbial load in the explant. Hence, in order to make the explants, microbial free, various antibiotics were tested for effective decontamination of the shoot tip explants. For this, the washed shoot tips were immersed in sterile distilled water containing $100 \mathrm{mgl}^{-1}$ of various antibiotics namely, rifampicin, ampicillin and gentamycin, each separately and incubated overnight for $8 \mathrm{hrs}$. Then the shoot tips were washed thoroughly with sterile distilled water and outer layer trimmed.

After the antibiotic treatment of banana suckers, the trimmed explants were taken to the laminar air flow chamber and subjected to various sterilizing agents like $4 \%$ sodium hypochlorite for 10 minutes, $0.1 \%$ mercuric chloride for 5 minutes and $70 \%$ ethanol for one minute followed by washing with sterile water for four times. The final trimming was done in explants and used for culture initiation. The percentage of contamination free explants and survival percentage of the explants were recorded after 10 days of inoculation of the shoot tip in initiation media and the appropriate sterilization process for effective explant sterilization is recorded.

\section{Shoot tip inoculation for initiation}

The explants were treated with the antioxidant solution containing ascorbic acid $100 \mathrm{mgl}^{-1}$ for 10 minutes to avoid blackening of the tissue due to phenolic exudation, washed thoroughly using sterile distilled water for three times and inoculated in MS media with various hormonal combinations of 6Benzylaminopurine (BAP) and 1-Naphthalene acetic acid (NAA) either BAP alone or in combination with NAA, both at various levels. The concentration of BAP tested for shoot initiation was $1 \mathrm{mgl}^{-1}$ and $2 \mathrm{mgl}^{-1}$ and NAA concentration was $0.1 \mathrm{mgl}^{-1}$ and $0.2 \mathrm{mgl}^{-1}$. The shoot tips were inoculated in the initiation media and incubated in the culture room at $25 \pm 2^{\circ} \mathrm{C}$ with $16 / 8 \mathrm{~h}$ photoperiod, $40 \% \mathrm{RH}$ and light intensity of 2000lux. During the initiation process, the number of days for explant greening and percentage of response to shoot tip initiation were observed after6 weeks of incubation in the initiation media.

\section{Sub culturing for shoot multiplication}

The culture media for shoot multiplication was prepared as MS basal media supplemented with combinations of BAP and NAA. The treatments were BAP alone ( 3 and $4 \mathrm{mgl}^{-1}$ ) and BAP in combination with NAA $\left(0.05 \mathrm{mgl}^{-1}\right.$ and $0.1 \mathrm{mgl}^{-}$ $\left.{ }^{1}\right)$. The contamination free initiated shoots were decapitated and split into two or more parts longitudinally and transferred to multiplication media. After 3 weeks of inoculation in shoot multiplication media, the observations like the number of days taken for multiple shoot formation, number of shoots per plant and shoot length were recorded. The sub-culturing was 
done in fresh shoot multiplication media after every 3 weeks for 5 times.

\section{In vitro rooting}

During every sub-culturing of once in 3 weeks, well grown plantlets were separated and transferred to rooting media. After $5^{\text {th }}$ subculture, all the shoots were cultured in $1 / 2 \mathrm{MS}$ media with combination of Indole-3butyric acid (IBA) and Indole-3-acetic acid (IAA). For rooting, the in vitro grown shoots of 4-5cmheight with expanded leaves were transferred to half strength MS medium supplemented with auxins, IBA $\left(0.5 \mathrm{mgl}^{-1}\right.$ and $1 \mathrm{mgl}^{-1}$ ) either alone or in combination with IAA $\left(0.5 \mathrm{mgl}^{-1}\right.$ and $\left.1 \mathrm{mgl}^{-1}\right)$. After 6 weeks of root development, the observations like number of days for root initiation, number of roots per shoot and root length were recorded.

\section{Acclimatization and Hardening}

The rooted plantlets were carefully detached from the medium without damaging the roots and washed thoroughly in running tap water to remove small pieces of agar adhering to the roots. These rooted plantlets of about $5-6 \mathrm{~cm}$ height and with 3 - 4 leaves were taken for primary hardening and roots dipped in the fungicide solution of $0.1 \%$ Bavistin and transferred to small pots filled with $200 \mathrm{~g}$ of cocopeat and maintained in a polyhouse with environmental conditions of $26 \pm 1{ }^{\circ} \mathrm{C}$ temperature, $85-90 \% \mathrm{RH}$ and 7000-8000 lux sunlight for 4 weeks.

The primary hardened plants were transferred to bigger pots containing $1 \mathrm{~kg}$ mixture of cocopeat, farm yard manure and sand in 1:1:1 ratio for secondary hardening under $50 \%$ shade net house at $40 \%$ RH for 4 weeks. Five plants in random were observed for mean performance in plant height, number of leaves per plant and root length after primary and secondary hardening.

\section{Experimental design and data analysis}

The treatments with three replications each were arranged in completely Randomized design (CRD). The experimental data were analysed using Multiple Analysis of Variance at $95 \%$ of confidence level. The means were separated according to Duncan Multiple Range Test (DMRT) when F-test showed statistical significance at $\mathrm{p}<0.05$ level.

\section{Results and Discussion}

\section{Explant sterilization}

The shoot tip explants of banana after pretreatment were subjected to sterilization using various antibiotics treatment and chemical sterilization in LAF. The results showed that $87.5 \%$ contamination free cultures were obtained by immersing the explants overnight in ampicillin $100 \mathrm{mgl}^{-}$ ${ }^{1}$ followed by chemical sterilization using $4 \%$ sodium hypochlorite for 10 minutes in LAF and the survival rate was $81.3 \%$ (Table 1 and Fig. 1). The antibiotics, cefotaxime, gentamycin, tetracycline, chloramphenicol, streptocyclin were found to be best in eliminating contaminants in banana explants (Leifert and Cassells, 21); (Fang and Hsu, 8); (Bohra et al., 4). The endogenous bacteria in banana were killed using ampicillin and tetracycline (Habiba et al., 11). Falkiner (1990) reported that the antibiotics which act on bacterial cell wall formation are efficient to produce contamination-free cultures. Ampicillin is a broad spectrum antibiotic and cell wall synthesis inhibitor (Reed et al., 38). Among the chemical sterilants used in LAF, $4 \%$ sodium hypochlorite treatment for 10 minutes was superior to $0.1 \%$ mercuric chloride for 5 minutes and $70 \%$ ethanol for one minute. Goswami (10) showed that the combination of $1 \%$ sodium hypochlorite for 15 minutes followed by $0.1 \% \mathrm{HgCl}_{2}$ for 7 minutes resulted in aseptic culture establishment in in vitro condition. Ahmed et 
al., (2014) documented considerable reduction in contamination of explant by increasing the concentration of sodium hypochlorite to $5 \%$ for 10 minutes exposure and eliminating $\mathrm{HgCl}_{2}$ treatment. In this study also banana shoot tip explant exposure to increased sodium hypochlorite concentration of $4 \%$ for 10 minutes resulted in $87.5 \%$ contamination free cultures and the survival rate was $81.3 \%$ which means that the explant was protected from harsh sterilization treatments of more than one chemical (Table $1)$.

\section{Shoot tip initiation}

The shoot tip explants in the first week of inoculation in the initiation media showed very light brown colouration externally and later became greenish and developed adventitious plantlets. The treatment, MS + BAP $2 \mathrm{mgl}^{-1}$ + NAA $0.1 \mathrm{mgl}^{-1}$ recorded earlier shoot initiation and explant greening in 7.7 days and percent response to initiation was 92.5\% compared to other hormonal combinations (Table 2 and Fig. 2). The significant effect of BAP in shoot initiation has been well documented in previous studies (Qamar et al., 2015). BAP is the most preferred cytokinin in banana tissue culture (Cronauer and Krikorian, 1984); (Vuylsteke, 1998); (Kumar and Krishna, 2015); (Prakasha et al., 2019). Meristem tip culture in Indian red banana, Musa acuminate produced highest shoot initiation and adventitious bud formation in the presence of BAP $2 \mathrm{mgl}^{-1}$ and NAA $0.2 \mathrm{mgl}^{-1}$ in the MS media (Rajoriya $e t$ al.,2018) (Table 2).

Table.1 Effect of sterilization on the survival rate of explants

\begin{tabular}{|c|c|c|c|c|}
\hline $\begin{array}{l}\text { S. } \\
\text { No }\end{array}$ & $\begin{array}{c}\text { Antibiotics } \\
\text { treatment }\end{array}$ & Chemical sterilization in LAF & $\begin{array}{l}\text { Contamination } \\
\text { free explants (\%) }\end{array}$ & $\begin{array}{l}\text { survival \% of } \\
\text { the explants }\end{array}$ \\
\hline 1. & \multirow{3}{*}{$\begin{array}{l}\text { Rifampicin } \\
100 \mathrm{mgl}^{-1}\end{array}$} & $4 \%$ sodium hypochlorite for 10 minutes & 62.5 & 56.2 \\
\hline 2. & & $0.1 \%$ mercuric chloride for 5 minutes & 57.1 & 45.7 \\
\hline 3. & & $70 \%$ ethanol for 1 minute & 42.8 & 35.7 \\
\hline 4. & \multirow{3}{*}{$\begin{array}{l}\text { Ampicillin } \\
100 \mathrm{mgl}^{-1}\end{array}$} & 4\% sodium hypochlorite for 10 minutes & 87.5 & 81.3 \\
\hline 5. & & $0.1 \%$ mercuric chloride for 5 minutes & 75.0 & 62.5 \\
\hline 6. & & $70 \%$ ethanol for 1 minute & 50.0 & 41.7 \\
\hline 7. & \multirow{3}{*}{$\begin{array}{c}\text { Gentamycin } \\
100 \mathrm{mg}^{-1}\end{array}$} & 4\% sodium hypochlorite for 10 minutes & 66.7 & 55.5 \\
\hline 8. & & $0.1 \%$ mercuric chloride for 5 minutes & 62.5 & 43.8 \\
\hline 9. & & $70 \%$ ethanol for 1 minute & 40.0 & 30.0 \\
\hline & \multicolumn{2}{|l|}{$\mathrm{CD}(0.05)$} & 2.81 & 2.46 \\
\hline
\end{tabular}

Table.2 Shoot initiation at various levels of cytokinin and auxin

\begin{tabular}{|l|l|c|c|}
\hline S. No & \multicolumn{1}{|c|}{ Treatments } & $\begin{array}{c}\text { No. of days for } \\
\text { explant greening }\end{array}$ & $\begin{array}{c}\text { \% response to } \\
\text { initiation }\end{array}$ \\
\hline 1. & MS+BAP $1 \mathrm{mgl}^{-1}$ & 10.7 & 70.0 \\
\hline $\mathbf{2 .}$ & MS+BAP $2 \mathrm{mgl}^{-1}$ & 8.5 & 85.7 \\
\hline $\mathbf{3 .}$ & MS+BAP $1 \mathrm{mgl}^{-1}+$ NAA $0.1 \mathrm{mgl}^{-1}$ & 9.3 & 71.4 \\
\hline $\mathbf{4 .}$ & MS+BAP $1 \mathrm{mgl}^{-1}+$ NAA $0.2 \mathrm{mgl}^{-1}$ & 9.5 & 75.0 \\
\hline $\mathbf{5 .}$ & MS+BAP $\mathrm{mgl}^{-1}+$ NAA $0.1 \mathrm{mgl}^{-1}$ & 7.7 & 92.5 \\
\hline 6. & MS+BAP $2 \mathrm{mgl}^{-1}+$ NAA $0.2 \mathrm{mgl}^{-1}$ & 8.3 & 87.5 \\
\hline & CD $(0.05)$ & 1.53 & 2.33 \\
\hline
\end{tabular}


Table.3 Shoot proliferation at various levels of cytokinin and auxin

\begin{tabular}{|c|c|c|c|c|}
\hline S.No & Treatments & $\begin{array}{l}\text { Days taken for multiple } \\
\text { shoot formation }\end{array}$ & $\begin{array}{l}\text { No. of shoots } \\
\text { per plant }\end{array}$ & $\begin{array}{c}\text { Shoot } \\
\text { length }(\mathrm{cm})\end{array}$ \\
\hline 1. & $\mathrm{MS}+\mathrm{BAP} 3 \mathrm{mg}^{-1}$ & 77.5 & 3.0 & 4.1 \\
\hline 2. & $\mathrm{MS}+\mathrm{BAP} 4 \mathrm{mg}^{-1}$ & 73.3 & 3.4 & 4.5 \\
\hline 3. & $\mathrm{MS}+\mathrm{BAP} 3 \mathrm{mg}^{-1}+\mathrm{NAA} 0.05 \mathrm{mg}^{-1}$ & 68.5 & 3.6 & 4.4 \\
\hline 4. & $\mathrm{MS}+\mathrm{BAP} 3 \mathrm{mg}^{-1}+\mathrm{NAA} 0.1 \mathrm{mg}^{-1}$ & 70.0 & 3.7 & 4.2 \\
\hline 5. & $\mathrm{MS}+\mathrm{BAP} 4 \mathrm{mg}^{-1}+\mathrm{NAA} 0.05 \mathrm{mg}^{-1}$ & 58.3 & 4.5 & 4.8 \\
\hline \multirow[t]{2}{*}{6.} & $\mathrm{MS}+\mathrm{BAP} 4 \mathrm{mg}^{-1}+\mathrm{NAA} 0.1 \mathrm{mg}^{-1}$ & 62.7 & 4.0 & 4.5 \\
\hline & $\mathrm{CD}(0.05)$ & 2.37 & 0.20 & 0.18 \\
\hline
\end{tabular}

Table.4 Root formation at various levels of auxins

\begin{tabular}{|c|c|c|c|c|}
\hline S.No & Treatments & $\begin{array}{l}\text { No. of days for } \\
\text { root initiation }\end{array}$ & $\begin{array}{l}\text { No. of roots } \\
\text { per shoot }\end{array}$ & $\begin{array}{c}\text { Root length } \\
(\mathrm{cm})\end{array}$ \\
\hline 1. & $1 / 2 \mathrm{MS}+\mathrm{IBA} 0.5 \mathrm{mgl}^{-1}$ & 12.7 & 6.7 & 4.0 \\
\hline 2. & $1 / 2 \mathrm{MS}+\mathrm{IBA} 1 \mathrm{mgl}^{-1}$ & 13.3 & 6.5 & 3.5 \\
\hline 3. & 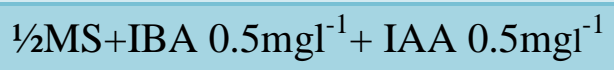 & 10.5 & 8.5 & 5.3 \\
\hline 4. & $1 / 2 \mathrm{MS}+$ IBA $0.5 \mathrm{mgl}^{-1}+\mathrm{IAA} 1 \mathrm{mgl}^{-1}$ & 12.0 & 7.5 & 4.5 \\
\hline 5. & $1 / 2 \mathrm{MS}+\mathrm{IBA} 1 \mathrm{mgl}^{-1}+\mathrm{IAA}^{0.5 \mathrm{mgl}^{-1}}$ & 14.0 & 6.3 & 4.2 \\
\hline \multirow[t]{2}{*}{6.} & $1 / 2 \mathrm{MS}+\mathrm{IBA}^{1} \mathrm{mgl}^{-1}+\mathrm{IAA} 1 \mathrm{mgl}^{-1}$ & 15.8 & 6.2 & 3.7 \\
\hline & $\mathrm{CD}(0.05)$ & 0.88 & 0.89 & 0.87 \\
\hline
\end{tabular}

Table.5 Growth of primary and secondary hardened plants

\begin{tabular}{|l|c|c|c|c|c|c|}
\hline \multirow{2}{*}{ S. No } & \multicolumn{3}{|c|}{ Primary hardening } & \multicolumn{3}{c|}{ Secondary hardening } \\
\cline { 2 - 7 } & $\begin{array}{c}\text { Plant height } \\
(\mathrm{cm})\end{array}$ & $\begin{array}{c}\text { No. of } \\
\text { leaves/plant }\end{array}$ & $\begin{array}{c}\text { Root length } \\
(\mathrm{cm})\end{array}$ & $\begin{array}{c}\text { Plant height } \\
(\mathrm{cm})\end{array}$ & $\begin{array}{c}\text { No. of } \\
\text { leaves/plant }\end{array}$ & $\begin{array}{c}\text { Root } \\
\text { length }(\mathrm{cm})\end{array}$ \\
\hline & 6.5 & 3.5 & 5.5 & 11.2 & 4.8 & 6.7 \\
\hline $\mathbf{1 .}$ & 7.0 & 4.3 & 6.0 & 10.8 & 5.0 & 7.3 \\
\hline 2. & 6.8 & 3.0 & 5.8 & 10.5 & 4.5 & 7.0 \\
\hline $\mathbf{3 .}$ & 7.2 & 4.1 & 6.2 & 11.0 & 6.0 & 7.5 \\
\hline $\mathbf{4 .}$ & 7.0 & 4.0 & 5.3 & 10.5 & 5.7 & 6.8 \\
\hline Mean & $\mathbf{6 . 9}$ & $\mathbf{3 . 8}$ & $\mathbf{5 . 8}$ & $\mathbf{1 0 . 8}$ & $\mathbf{5 . 2}$ & $\mathbf{7 . 1}$ \\
\hline
\end{tabular}


Fig.1-7 Micropropagation of banana var. Matti by shoot tip culture

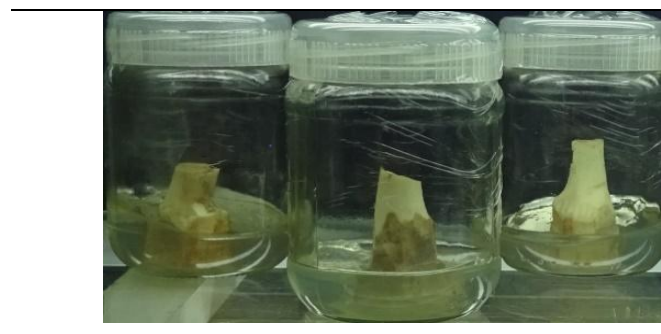

Fig.1 Shoot tip inoculation

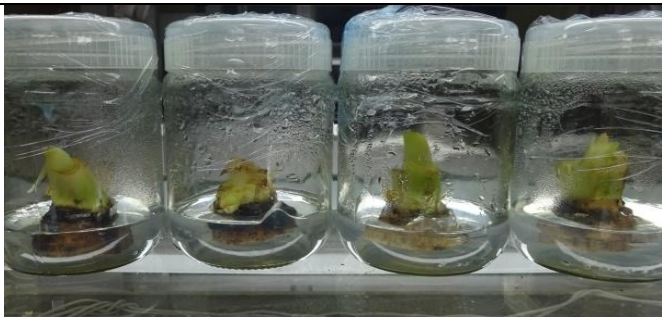

Fig.2 Greening and initiation of shoot tip

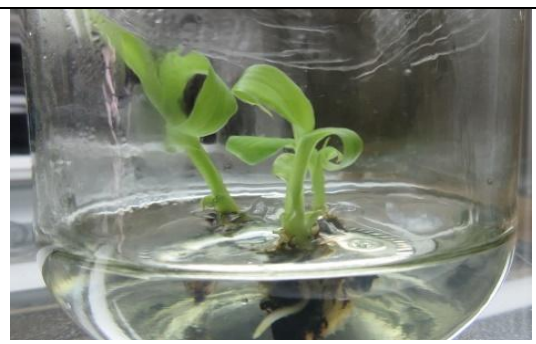

Fig.4 In vitro rooting

Fig.3 Multiple shoot formation

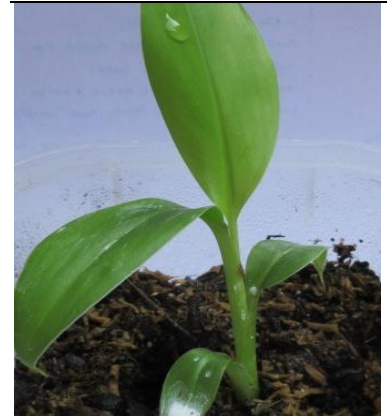

Fig.5. Primary hardened plant

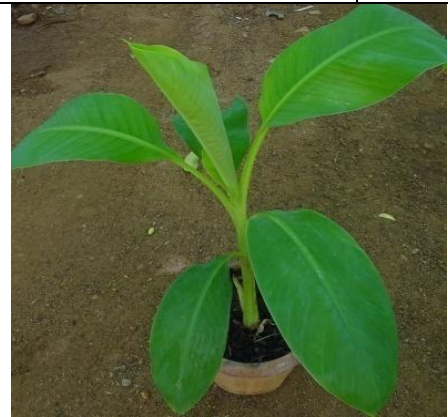

Fig.6. Secondary hardened plant

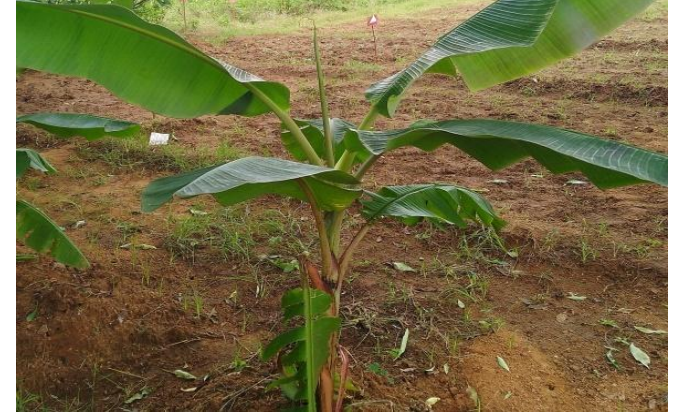

Fig.7. TC banana planted in field

\section{Multiple shoot formation}

The shoot tip explant after initiation for 6 weeks, when one leaf emerged, it was sliced and transferred to shoot multiplication media. The combined effect of BAP and NAA in multiple shoot formation resulted in efficient proliferation in the media, MS+BAP $4 \mathrm{mg}^{-1}+$ NAA $0.05 \mathrm{mg}^{-1}$ wherein the number of days taken for multiple shoot initiation was 58.3days, number of shoots per plant was 4.5 and the shoot length was $4.8 \mathrm{~cm}$ (Table 3 and Fig. 3). The reduction of apical dominance and induction of axillary and adventitious buds in banana shoot tip explants was achieved by the cytokinin, BAP (Jafari et al., 2011). Even though cytokinin is sufficient to induce multiple shoots, addition of auxins enhanced the number of shoots formed (Mukunthakumar and Seeni, 2005). BAP in medium concentration performed well for multiple shoot formation and higher 
concentration had declining effect (Lohidas and Sujin, 2015). Shoot proliferation occurs in MS media with BAP concentration of up to $5 \mathrm{mgl}^{-1}$ (Rahman et al., 2004); (Radhika and Amutha, 2013) and the combination of BAP and NAA showed enhanced shoot multiplication and growth (Prabhuling et al., 2017); (Deepika et al., 2018); (Hoque et al., 2018) (Table 3).

\section{In vitro rooting}

After shoot proliferation in 5 subcultures, all the shoots were cultured in $1 / 2 \mathrm{MS}$ media with combination of IBA and IAA. The root initiation was earlier in half MS media with IBA $0.5 \mathrm{mgl}^{-1}$ and IAA $0.5 \mathrm{mg}^{-1}$ in 10.5 days of transfer of shoots to this rooting media. And in 6 weeks of culturing, the number of roots formed was 8.5 per shoot and root length was $5.3 \mathrm{~cm}$ in the same hormonal treatment (Table 4 and Fig. 4). Even though growth hormones are not essential for in vitro root formation (Jarret et al., 1985), addition of auxins induce better root formation (Vuylsteke, 1998); (Kelta et al.,2018). The root development was superior by using IBA and IAA in combination(Al-Amin et al., 2009); (Deepika et al.,2018 (Kelta et al., 2018). In the present study, the plantlets developed completely in 50 days after transferring to rooting media and were ready for acclimatization even though, Berg and Bustamante, 1974 reported the need of 2 to 3 months for in vitro rooting (Table 4).

\section{Acclimatization and hardening of plantlets}

During the hardening phase, mortality is expected due to changes in the growth conditions (Pati et al., 2018) and to overcome this problem both primary and secondary hardening is necessary for acclimatization of the plantlets to in vivo conditions. In this study hardening produced plants with $100 \%$ survival. Primary hardened plants recorded the plant height of $6.9 \mathrm{~cm}$, leaf numbers of 3.8 per plant and root length of $5.8 \mathrm{~cm}$. After secondary hardening, the plantlets reached the plant height of $10.8 \mathrm{~cm}$, leaf numbers of 5.2 per plant and root length of $7.1 \mathrm{~cm}$ (Table 5 ; Fig. 5, $6 \& 7$ ). The hardened plants were then transferred to field showing normal growth. Acclimatization was optimum using press mud cake with soil for producing sturdy plants during hardening (Vasane and Kothari, 1998). Kishor et al., (2017) used cocopeat and vermiculite in 1:1 ratio for optimum growth and development. Karule et al., (2016) reported acclimatization of plantlets in polyhouse, followed by shadenet house under $50 \%$ sunlight and the plants showed luxurious growth in field (Table 5) (Fig. 1-7).

In conclusion the Musa acuminata cv. Matti otherwise called Dhevankadali is an economic species of the southern ranges of Western Ghats and hence the present research findings will help to disseminate this variety for large scale cultivation. Based on the observations and results obtained in this study, an efficient protocol has been developed for shoot tip explant sterilization and in vitro regeneration of the banana cv. Matti. This protocolcan be followed for mass scale production of plantlets within a short span through micropropagation. At the same time, establishment of disease free and true to type plants with uniform maturity could be achieved in the field planting. This in vitro regeneration protocol for banana cv. Matti will be used for mass multiplication in order to produce plantlets for cultivation in various geographical areas.

\section{Conflict of Interests}

The authors have not declared any conflict of interests.

\section{References}

Ahmed, Shahnawaz, Akash Sharma, Singh, A.K., Wali, V.K. and Preeti Kumari. 2014. In vitro multiplication of banana 
(Musa sp.) cv. Grand Naine.African Journal of Biotechnology. 13.

Al-Amin, M.D., Karim, M.R., Amin, M.R., Rahman, S. and Mamun, A.N.M. 2009. In vitro micropropagation of banana. Bangladesh Journal of Agricultural Research.34: 645-659.

Berg, Lloyd, A. and Mario Bustamante. 1974. Heat treatment and meristem culture for the production of virus-free bananas. Phytopathology.

Bohra, Pooja, Ajit Arun Waman, Sathyanarayana, B.N. and Umesha, K. 2013. Preliminary assessment of intraclonal variability in Indian banana varieties for sucker production.

Cronauer, Sandra, S. and Krikorian, A.D. 1984. Multiplication of Musa from excised stem tips. Annals of Botany.53: 321-328.

Deepika, C., Basanti, B., Singh, D.J., Subhash, K. and Anil, P. 2018. An insight into in vitro micropropagation studies for banana-Review. Intl. J. Agr. Sci10:5346-5349.

Falkiner, F.R. 1990. The criteria for choosing an antibiotic for control of bacteria in plant tissue culture.

Fang, Jong-Yi. and Yu-Rong Hsu. 2012. Molecular identification and antibiotic control of endophytic bacterial contaminants from micropropagated Aglaonema cultures. Plant Cell, Tissue and Organ Culture (PCTOC)110: 5362.

Gaspar, T.H., Claire Kevers, Odile FaivreRampant, CrC, Penel, C.L., Hubert Greppin. and Jacques Dommes. 2003. Changing concepts in plant hormone action. In Vitro Cellular \& Developmental Biology-Plant, 39: 85.

Goswami. 2013. Explants size response to in vitro propagation of Musa (AAA Group). Indian Journal of Applied Research.

Habiba, Ummey, Sharmin Reza, Mihir Lal
Saha, Khan, M.R. and Syed Hadiuzzaman. 2002. Endogenous bacterial contamination during in vitro culture of table banana: Identification and prevention. Plant Tissue Cult 12: 117-124.

Hoque, Farhana, Mahbub Robbani, Md Fakhrul Hasan and Jahanara Parvin. 2018. Standardization of protocol for in vitro propagation of banana (Musa sapientum). Journal of the Bangladesh Agricultural University.16: 27-30.

Israeli, Yair, Dahlia Ben-Bassat. and Oded Reuveni. 1996. Selection of stable banana clones which do not produce dwarf somaclonal variants during in vitro culture. Scientia Horticulturae. 67: 197-205.

Jafari, Najmeh, Rofina Yasmin Othman. and Norzulaani Khalid. 2011. Effect of benzylaminopurine (BAP) pulsing on in vitro shoot multiplication of Musa acuminata (banana) cv. Berangan. African Journal of Biotechnology. 10: 2446-2450.

Jarret, R.L., Fisher, J.B. and Litz, R.E. 1985. Organ formation in Musa tissue cultures. Journal of plant physiology.121:123-130.

Karule, P., Dalvi, V., Kadu, A., Chaudhari, R., Subramaniam, V.R. and Patil, A.B. 2016. A commercial micropropagation protocol for Virupakshi (AAB) banana via apical meristem. African Journal of Biotechnology.15: 401-407.

Kelta, Alango, Sunil Hajare. and Akilu Banjaw. 2018. Studies on in vitro Micropropagation in Banana. Int. J. Curr. Microbiol. App. Sci.7: 33663375.

Kishor, H., Abhijith, Y.C. and Manjunatha, N. 2017. Micropropagation of native cultivars of Banana-A Critical Review. International Journal of Pure and Applied Bioscience.5:1559-1564.

Kumar, R., Shashi. and Krishna, V. 2015. 
High Frequency Plant Regeneration of Musa paradisiaca cv. Karibale Monthan. International Journal of Applied Sciences and Biotechnology. 3: 202-209.

Leifert, C. and Waites, W.M. 1994. Dealing with microbial contaminants in plant tissue and cell culture: hazard analysis and critical control points. InPhysiology, Growth and Development of Plants in Culture. 363378.

Leifert, Cassells. and Cassells, A.C. 2001. Microbial hazards in plant tissue and cell cultures. In Vitro Cellular \& Developmental Biology-Plant.37:133138.

Lohidas, J. and Sujin, D. 2015. Effect of growth hormones in the micro propagation of banana CV. Matti. Plant Archives.15: 307-314.

Mendes, Beatriz, M.J., Fernanda Mendes, Augusto Tulmann Neto, Clarice Garcia Borges trio. and Ricardo Puske, O. 1996. Efficacy of banana plantlet production by micropropagation. Pesquisa AgropecuClria Brasileira. 31:863-868.

Molla, M.H., Dilafroza Khanam, M., Khatun, M.M., Al-Amin, M. and Malek, M.A. 2004. In vitro rooting and Ex vitro plantlet establishment of BARI Banana-I (Musa sp.) as influenced by different concentrations of IBA (Indole 3-butyric Acid). Asian Journal of Plant Sciences. 3:196-199.

Muhammad, Aish, Iqbal Hussain, Saqlan Naqvi, S.M. and Hamid Rashid. 2004. Banana plantlet production through tissue culture. Pakistan Journal of Botany.36: 617-620.

Mukunthakumar, S. and Seeni, S. 2005. In vitro cloning and homestead cultivation of primitive Musa cultivars.

Ngomuo. 2013. The effects of auxins and cytokinin on growth and development of (Musa sp.) var.b.

Pati, Rajesh, Maneesh Mishra, Ramesh Chandra. and Muthukumar, M. 2013. Histological and Biochemical Changes in Aegle marmelos Corr. before and after Acclimatization. Tree Genetics and Molecular Breeding.3.

Pierik, R.L.M. 1987. In vitro culture of higher plants as a tool in the propagation of horticultural crops.

Prabhuling. 2017. Liquid medium culture method for rapid multiplication of banana (Musa acuminata) cv.b.

Pradhan, Bikram. and Bandita Deo. 2019. Detection of phytochemicals and in vitro propagation of Banana (Musa variety Gaja Bantal). Journal of Medicinal Plants. 7: 46-49.

Prakasha, Devalakere, Gurunath Ramya, Ryavalad Shivayogi, Kustagi Gajanana. and Krishnappa Kattimani. 2019. In Vitro Mass Propagation System in Banana Cv. Kamalapur Red (AAA). Research Journal of Biotechnology. 14:5.

Qamar, Mehnaz, Sadaf Tabassum Qureshi, Imtiaz Ahmed Khan. and Saboohi Raza. 2015. Optimization of in vitro multiplication for exotic banana (Musa spp.) in Pakistan. African Journal of Biotechnology. 14: 1989-1995.

Radhika, Ramachandran. and Amutha, K. 2013. In vitro micropropagation of Banana (Musa spp.) by variant concentration of growth regulators. International J. Frontiers Sci. Tech.1:98-104.

Rahman, M.Z., Nasiruddin, K.M., Amin, M.A. and. Islam, M.N. 2004. In vitro response and shoot multiplication of banana with BAP and NAA. Asian $J$. Plant Sci.3:406-409.

Rajoriya, Preeti, Vivek Kumar Singh. and Nancy Jaiswaland Rohit Lall. 2018. Optimizing the effect of plant growth regulators on in vitro micro propagation 
of Indian red banana (Musa acuminata). Journal of Pharmacognosy and Phytochemistry.8:628-634.

Razani, Muslim, Fatimah Kayat, Raimi Mohamed Redwan. and Dwi Susanto. 2019. Effect of Somaclonal Variation in Musa acuminata cv. Berangan Through Micropropagation Using RAPD. Biotechnology.18: 9-14.

Reed, Barbara M., Patricia, M., Buckley. and TracIi DeWilde. 1995. Detection and eradication of endophytic bacteria from micropropagated mint plants. In Vitro Cellular \& Developmental BiologyPlant.31: 53-57.

Rustagi, Anjana, Shalu Jain, Deepak Kumar, Shashi Shekhar, Mukesh Jain, Vishnu Bhat, and. Neera Bhalla Sarin. 2015. High efficiency transformation of banana (Musa acuminata L. cv. Matti(AA)) for enhanced tolerance to salt and drought stress through overexpression of a peanut salinityinduced pathogenesis-related class 10 protein. Molecular biotechnology.57:
27-35.

Sipen, Philip. and Michael Davey, R. 2012. Effects of N6-benzylaminopurine and indole acetic acid on in vitro shoot multiplication, nodule-like meristem proliferation and plant regeneration of Malaysian bananas (Musa spp.). Tropical life sciences research. 23:67.

Titov, Soubir, Salil Kumar Bhowmik, Ajoy Mandal, Md Sadrul Alam and Sarder Nasir Uddin. 2006. Control of phenolic compound secretion and effect of growth regulators for organ formation from Musa spp. cv.Kanthali floral bud explants. Am. J. Biochem. Biotechnol.2:97-104.

Vasane, Shailesh, R. and Kothari, R.M. 2006. Optimization of secondary hardening process of banana plantlets (Musa paradisiaca $L$. var. grand nain).

Vuylsteke, D.R. 1998. Shoot-tip culture for the propagation, conservation and distribution of Musa germplasm: IITA.

\section{How to cite this article:}

Merina Prem Kumari, S., S. Saravanan and Arumugam Pillai, M. 2020. In vitro Propagation of Medicinally Valuable Traditional Banana Cultivar, Musa acuminata cv. Matti by Shoot Tip Culture. Int.J.Curr.Microbiol.App.Sci. 9(08): 2240-2250.

doi: https://doi.org/10.20546/ijcmas.2020.908.257 